\title{
Grazing on Microcystis aeruginosa by the heterotrophic flagellate Collodictyon triciliatum in a hypertrophic pond
}

\author{
Yuichiro Nishibe ${ }^{1, *}$, Zen'ichiro Kawabata ${ }^{2}$, Shin-ichi Nakano ${ }^{1}$ \\ ${ }^{1}$ Center for Marine Environmental Studies, Ehime University, Bunkyo-cho 3, Matsuyama, Ehime 790-8577, Japan \\ ${ }^{2}$ Center for Ecological Research, Kyoto University, Kamitanikami Hirano-cho 509-3, Otsu, Shiga 520-2113, Japan
}

\begin{abstract}
Temporal changes in abundance of the heterotrophic flagellate Collodictyon triciliatum and its grazing rates on Microcystis aeruginosa were examined in a hypertrophic pond during a bloom of the cyanobacterium in 2000. The rates were estimated from ingested cells of $M$. aeruginosa in food vacuoles of $C$. triciliatum and experimentally determined digestion rates of the flagellate feeding on the cyanobacterium. Cell densities of $C$. triciliatum fluctuated between 10 and 510 cells $\mathrm{ml}^{-1}$, and the changing pattern was different from that of $M$. aeruginosa. Single cells and small colonies of $M$. aeruginosa were found in food vacuoles of the flagellate, ranging between 2.9 and 16.7 cells flagellate ${ }^{-1}$. The digestion rate of $C$. triciliatum was determined as $0.74 \pm 0.02 \%$ cell contents $\mathrm{min}^{-1}$. Estimates of grazing rate on $M$. aeruginosa by $C$. triciliatum ranged between 1.1 and 9.9 M. aeruginosa cells flagellate ${ }^{-1} \mathrm{~h}^{-1}$, and grazing impact on the cyanobacterial standing stock fluctuated between 0.002 and $0.09 \% \mathrm{~h}^{-1}$ in the pond. It is estimated that consumption of $M$. aeruginosa supplies carbon to the flagellate at a rate of $5.5 \pm 3.2 \%$ to its cellular carbon content per hour. The growth rates of the flagellate are estimated as $0.016 \pm 0.009 \mathrm{~h}^{-1}$, which overlap those in previous laboratory studies. Hence, grazing on $M$. aeruginosa by $C$. triciliatum is probably of minor importance for the loss of cyanobacterial abundance in the pond, though the cyanobacterium is possibly an important food for the flagellate.
\end{abstract}

KEY WORDS: Microcystis aeruginosa $\cdot$ Heterotrophic flagellate $\cdot$ Digestion · Grazing rate

\section{INTRODUCTION}

Cyanobacterial blooms have been reported in many eutrophic and hypertrophic lakes, most commonly as Microcystis aeruginosa (Reynolds et al. 1981). The physiological and ecological characteristics of $M$. aeruginosa have been intensively studied, and the bloom-forming mechanisms clarified (e.g. Reynolds et al. 1981, Paerl et al. 1983, Takamura et al. 1985, Zohary \& Robarts 1989, Nakano et al. 2001a). However, the processes of loss from $M$. aeruginosa populations are not yet fully understood.

${ }^{*}$ Present address: Graduate School of Fisheries Sciences, Hokkaido University, 3-1-1 Minato-cho, Hakodate, Hokkaido 041-8611, Japan. E-mail: nishibe@fish.hokudai.ac.jp
Protists can be important consumers of bloom-forming cyanobacteria (e.g. Dryden \& Wright 1987). Previous studies have noted that some species of flagellates graze on Microcystis aeruginosa (Cole \& Wynne 1974, Sugiura et al. 1992, Klaveness 1995, Zhang et al. 1996). In particular, Cole \& Wynne (1974) and Sugiura et al. (1992) have reported active grazing by flagellates on $M$. aeruginosa in laboratory experiments. Hence, flagellate grazing may contribute to the decline of $M$. aeruginosa biomass, but little is known about the abundance of flagellates which graze on $M$. aeruginosa and their grazing rates on the cyanobacterium in natural environments. Even less is known about the role of cyanobacteria in the natural diet of flagellates.

There are various functional groups of protists, based on their different feeding modes, which sug- 
gests that there may be a limited number of species which could graze on Microcystis aeruginosa. Thus, it is important to examine the grazing rates on $M$. aeruginosa by a particular species. Grazing rates on phytoplankton by particular protistan species have so far been estimated using 2 methods: tracer techniques with fluorescently labeled algae (Rublee \& Gallegos 1989, Sherr et al. 1991, Mischke 1994, Šimek et al. 1996, Kamiyama et al. 2001), and the vacuole content method (Fenchel 1975, Kopylov \& Tumantseva 1987, Dolan \& Šimek 1997, 1998, Li et al. 2001). For the former, fluorescent staining of colonies of $M$. aeruginosa is required to determine the grazing rate of the protists; however, $M$. aeruginosa in culture usually forms small colonies and/or becomes unicellular, which is different from the colonies formed by $M$. aeruginosa in natural environments and may thus yield grazing rates different from those on $M$. aeruginosa in natural environments, since protistan grazing is in most cases size-selective (Chrzanowski \& Šimek 1990, Gonzalez et al. 1990, Šimek \& Chrzanowski 1992). In contrast, in the second method, grazing rates on $M$. aeruginosa by protists is based on digestion rates determined in laboratory experiments and the food vacuole contents of protists collected from natural environments. We therefore consider that the latter method is more appropriate for estimating grazing rates of protists feeding on $M$. aeruginosa.

In the fall of 1998, based on microscopic observations of food vacuole contents, we found that the heterotrophic flagellate Collodictyon triciliatum Carter was a grazer of Microcystis aeruginosa in a hypertrophic pond. Although it has been reported that this flagellate grows on M. aeruginosa (Klaveness 1995), grazing rate has never been examined. In the present study, we estimated grazing rates of $C$. triciliatum feeding on $M$. aeruginosa during a bloom of the cyanobacterium in a hypertrophic pond, by examining the ingested cells of $M$. aeruginosa in its food vacuoles, and determining the digestion rates of the flagellate feeding on the cyanobacterium in laboratory experiments. Grazing impacts by $C$. triciliatum on $M$. aeruginosa populations and importance of the cyanobacterium as food for the flagellate were also examined.

\section{MATERIALS AND METHODS}

Field investigation. Investigations were conducted in Furuike Pond which is located in Sancho, Matsuyama City, Ehime Prefecture, Japan. The pond has a surface area of ca. $7400 \mathrm{~m}^{2}$, and its maximum depth was $1.5 \mathrm{~m}$; it is hypertrophic due to anthropogenic loading from the watershed, and Microcystis aeruginosa forms heavy blooms from early summer to fall every year (Nakano et al. 1998, Manage et al. 1999, 2001). Physical and chemical characterizations of this pond are described in Nakano et al. (2001b).

Water samples were collected from the surface with a 151 plastic bucket at the near-shore station (Nakano et al. 1998), twice a week from 24 August to 17 October 2000. All samples were taken at around the same time of day (09:30 to 10:30 h) and water temperature was measured simultaneously with a thermistor (TOA Electronics).

To determine chlorophyll a (chl a) concentration, samples were filtered through a $0.2 \mu \mathrm{m}$ Nuclepore filter to retain seston. The filter was then transferred into a glass tube containing $6 \mathrm{ml}$ of $\mathrm{N}, \mathrm{N}$-dimethylformamide to extract the chlorophyll and kept in a freezer at $-20^{\circ} \mathrm{C}$. The chl a concentration was determined by the fluorometric method (Moran \& Porath 1980).

Immediately after collection, a $100 \mathrm{ml}$ portion of water sample was fixed with acidified Lugol's solution, at a final concentration of $1 \%$, and concentrated by natural sedimentation for enumeration of Microcystis aeruginosa. The concentrated sample was slightly sonicated (50 kw, $3 \mathrm{~min}$ ) to disintegrate colonies of $M$. aeruginosa, and cells of the cyanobacterium were counted in a Burker-Turk type haemacytometer under a microscope at a magnification of $400 \times$ at least 3 times.

For enumeration of Collodictyon triciliatum, another $100 \mathrm{ml}$ portion of water sample was fixed and concentrated as described above. C. triciliatum cells were counted in a Fuchs-Rosenthal type haemacytometer under a microscope at a magnification of $400 \times$ at least 3 times.

To examine the food vacuoles of Collodictyon triciliatum, a $100 \mathrm{ml}$ water sample was immediately fixed with $4 \%$ buffered glutaraldehyde at a final concentration of $2 \%$. The temperature of the fixative was adjusted to be the same as in situ water temperature. A preliminary experiment had shown that cell breakage due to fixation was minimal with fixation using $4 \%$ temperature-adjusted, buffered glutaraldehyde compared to use of $4 \%$ ice-cold, buffered glutaraldehyde (Sanders et al. 1989), 20\% temperature-adjusted glutaraldehyde or $20 \%$ ice-cold glutaraldehyde. Each fixed sample was concentrated by natural sedimentation, a $0.05 \mathrm{ml}$ aliquot of the concentrated sample containing $C$. triciliatum was mounted on a glass slide, 30 to 40 cells of $C$. triciliatum were observed under a microscope at a magnification of $400 \times$, and Microcystis aeruginosa in their food vacuoles were counted. Average numbers of ingested $M$. aeruginosa cells per flagellate were calculated for each sample.

Digestion experiment. Collodictyon triciliatum were isolated from the surface water of Furuike Pond in late 
June 2000. The strain was clonal but not axenic. Cultures were kept in sterile, filtered $(0.2 \mu \mathrm{m}$ Nuclepore filter) pond water with Microcystis aeruginosa NIES-298 $\left(2.0\right.$ to $6.0 \times 10^{6}$ cells $\left.\mathrm{ml}^{-1}\right)$ provided by the National Institute of Environmental Studies, Japan. All cultures were maintained in $30 \mathrm{ml}$ borosilicate tubes at $25^{\circ} \mathrm{C}$ under a light intensity of $48.8 \mu \mathrm{E} \mathrm{m} \mathrm{m}^{-2} \mathrm{~s}^{-1}$ with a 12:12 h light:dark cycle.

We followed Dolan \& Šimek (1998) to determine the digestion rates of Collodictyon triciliatum on Microcystis aeruginosa. A $6 \mathrm{ml}$ portion of the flagellate culture in its early stationary phase was inoculated into a $50 \mathrm{ml}$ polypropylene tube containing $12 \mathrm{ml}$ of $M$. aeruginosa culture $\left(4.0 \times 10^{6}\right.$ cells ml-1 $)$. The flagellate was allowed to ingest the cyanobacterium for $12 \mathrm{~h}$ at $25^{\circ} \mathrm{C}$ in the dark. To halt ingestion, the flagellate culture was diluted by adding $6 \mathrm{ml}$ of the mixture to $600 \mathrm{ml}$ of filtered pond water (GF-75 glass fiber filter, Advantec) in triplicate 11 Erlenmeyer flasks. The triplicate, diluted mixtures were incubated at $25^{\circ}$ in the dark. The incubation temperature was equal to the average water temperature $\left(25^{\circ} \mathrm{C}\right)$ measured in the field investigation. Fifty milliliter subsamples were taken from each flask at 30 to $120 \mathrm{~min}$ intervals for $360 \mathrm{~min}$, and fixed with $4 \%$ temperature-adjusted $\left(25^{\circ} \mathrm{C}\right)$, buffered glutaraldehyde at a final concentration of $2 \%$. Each fixed sample was concentrated by natural sedimentation, and a $0.05 \mathrm{ml}$ aliquot of the concentrated sample containing $C$. triciliatum was mounted on a glass slide. One hundred cells of $C$. triciliatum were observed under an epifluorescence microscope at a magnification of $640 \times$ under green excitation, and $M$. aeruginosa in the food vacuoles of the flagellates were enumerated using chlorophyll autofluorescence.

The slope of the linear regressions of $\ln (\%$ initial average numbers of ingested $M$. aeruginosa per flagellate) versus time yield the digestion rate, and multiplying the slope by 100 gives a digestion rate constant, with units of \% cell contents $\mathrm{min}^{-1}$ (Dolan \& Šimek 1998).

Estimation of grazing rate. To estimate in situ grazing rates of Collodictyon triciliatum on Microcystis aeruginosa, a steady state between ingestion and digestion (Dolan \& Šimek 1999) of the flagellate was assumed, and the digestion rate at $25^{\circ} \mathrm{C}$ was corrected for in situ temperature using $Q_{10}=2.1$ calculated from Mischke (1994). Estimates of grazing rate of C. triciliatum $\left(G_{\mathrm{C}}, M\right.$. aeruginosa cells flagellate $\left.{ }^{-1} \mathrm{~h}^{-1}\right)$ were calculated by multiplying the corrected digestion rate by the average numbers of ingested $M$. aeruginosa cells per flagellate for each sampling day, respectively. Estimates of clearance rate of $C$. triciliatum (nl flagellate ${ }^{-1}$ $\mathrm{h}^{-1}$ ) were calculated by dividing the grazing rate by the cell densities of $M$. aeruginosa for each sampling day. Hourly grazing impact on the standing stock of $M$. aeruginosa by $C$. triciliatum $\left(\mathrm{G}_{\mathrm{i}}, \%\right.$ standing stock $\left.\mathrm{h}^{-1}\right)$ was estimated as follows:

$$
G_{\mathrm{i}}=100 \times\left(G_{\mathrm{C}} \times N_{\mathrm{C}}\right) / N_{\mathrm{m}}
$$

where $N_{\mathrm{c}}\left(\right.$ cells $\left.\mathrm{ml}^{-1}\right)$ and $N_{\mathrm{m}}\left(\right.$ cells $\left.\mathrm{ml}^{-1}\right)$ are the cell densities of $C$. triciliatum and $M$. aeruginosa for each sampling day, respectively.

\section{RESULTS}

Surface water temperature (Fig. 1A) gradually decreased from 24 August $\left(29.6^{\circ} \mathrm{C}\right)$ to 17 October $\left(20.8^{\circ} \mathrm{C}\right) . \mathrm{Chl}$ a concentrations (Fig. 1A) increased from 24 August (389.0 $\left.\mathrm{gg} \mathrm{l}^{-1}\right)$ to 1 September $\left(581.2 \mu \mathrm{g} \mathrm{l}^{-1}\right)$, but decreased sharply from $5\left(546.4 \mu \mathrm{g} \mathrm{l^{-1 }}\right)$ to 8 September (213.2 $\mu \mathrm{g} \mathrm{l}^{-1}$ ). Concentrations of chl a fluctuated between 242.4 and $326.5 \mu \mathrm{g} \mathrm{l}^{-1}$ from 11 September onwards.

Microcystis aeruginosa was the predominant phytoplankton species during the study period, and the pattern of changes in cell densities of the cyanobacterium was similar to that of the chl a concentrations (Fig. 1A,B). The cell densities of $M$. aeruginosa varied from 0.96 to $2.6 \times 10^{6}$ cells $\mathrm{ml}^{-1}$ during the study period.
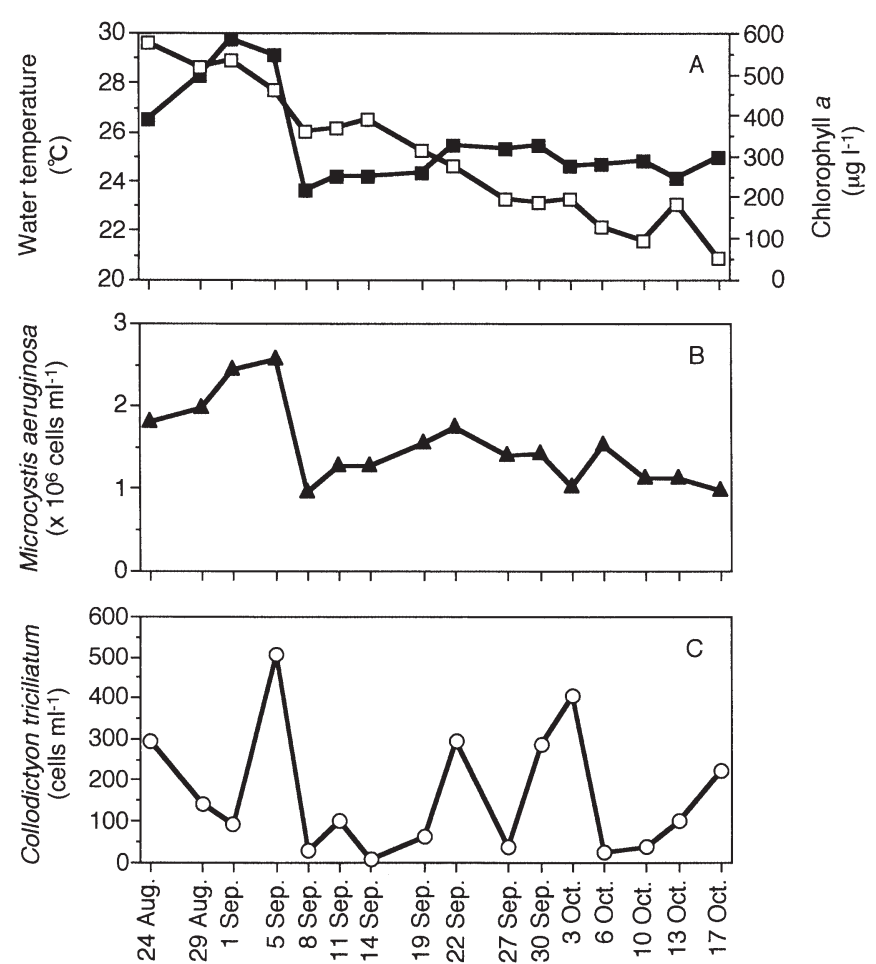

Fig. 1. Changes in (A) water temperature ( $\square)$, chl a concentration ( $\mathbf{\square})$, and cell densities of (B) Microcystis aeruginosa and (C) Collodictyon triciliatum in Furuike Pond during the study period 


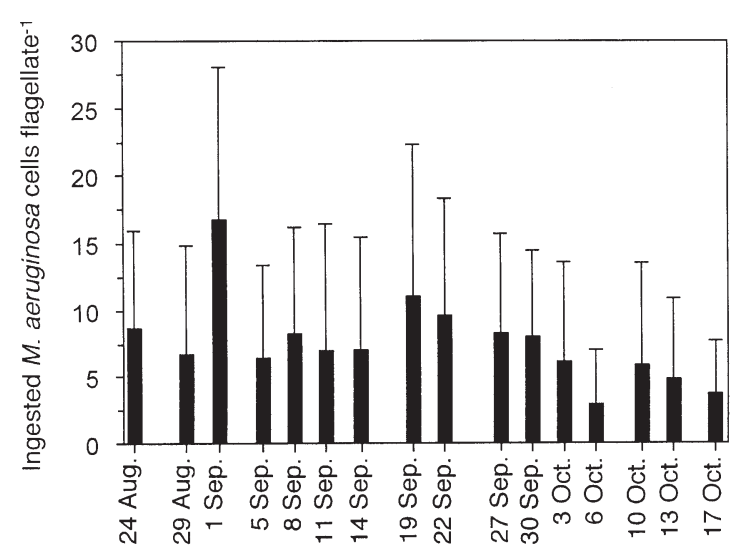

Fig. 2. Changes in average numbers of ingested Microcystis aeruginosa in the food vacuoles of Collodictyon triciliatum in Furuike Pond during the study period. Error bars indicate $+\mathrm{SD}$

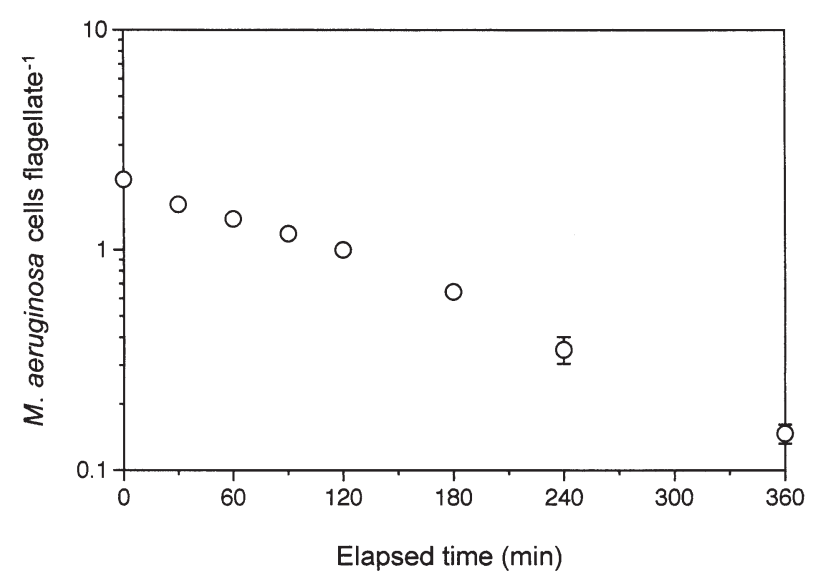

Fig. 3. Time-course of changes in average numbers of Microcystis aeruginosa in the food vacuoles of Collodictyon triciliatum. Error bars, which indicate $\pm \mathrm{SE}$, are shown when they exceed the size of the symbol

Cell densities of Collodictyon triciliatum fluctuated largely from 10 to 510 cells $\mathrm{ml}^{-1}$ and 3 sharp peaks of that were detected, on 5 and 22 September and from 30 September to 3 October (Fig. 1C). The abundance of C. triciliatum was not related to water temperature, chl a concentration and cell densities of $M$. aeruginosa (Fig. 1).

The percentage of Collodictyon triciliatum which ingested Microcystis aeruginosa varied from 56.7 to $97.1 \%$. The contribution of $M$. aeruginosa cells to the total numbers of ingested prey cells in food vacuoles of the flagellate varied from 22.7 to $96.4 \%$. The flagellate ingested not only single cells but also small colonies ( 2 to 51 cells) of $M$. aeruginosa. Average numbers of ingested $M$. aeruginosa cells by 1 flagellate ranged from 2.9 to 16.7 during the study period (Fig. 2), and
Table 1. Estimates of grazing and clearance rate of Collodictyon triciliatum feeding on Microcystis aeruginosa. Hourly grazing impacts of $C$. triciliatum on the standing stock of M. aeruginosa are also shown

\begin{tabular}{|lcc|}
\hline & Range & Mean $\pm \mathrm{SD}$ \\
\hline $\begin{array}{l}\text { Grazing rate } \\
\left(M . \text { aeruginosa cells flagellate }{ }^{-1} \mathrm{~h}^{-1}\right)\end{array}$ & $1.1-9.9$ & $3.6 \pm 2.1$ \\
$\begin{array}{l}\text { Clearance rate } \\
\left(\mathrm{nl} \text { flagellate } \mathrm{h}^{-1}\right)\end{array}$ & $0.69-4.1$ & $2.3 \pm 0.9$ \\
$\begin{array}{l}\text { Hourly grazing impact } \\
\left(\% \text { standing stock } \mathrm{h}^{-1}\right)\end{array}$ & $0.002-0.09$ & $0.04 \pm 0.03$ \\
\hline
\end{tabular}

remained high until 19 September. They tended to decrease from 22 September onwards. Numbers of $M$. aeruginosa cells found in flagellate vacuoles appeared to be independent of $M$. aeruginosa concentration (Figs. 1B \& 2).

In the digestion experiment, the average number of Microcystis aeruginosa cells per flagellate declined exponentially with time (Fig. 3), and a highly significant relationship was found between the $\ln (\%$ initial average numbers of ingested $M$. aeruginosa per flagellate) and time ( $\mathrm{r}=0.996, \mathrm{p}<0.0001, \mathrm{n}=8)$. The calculated digestion rate constant of Collodictyon triciliatum feeding on $M$. aeruginosa was $0.74 \pm 0.02 \%$ cell contents $\min ^{-1}$ (mean $\pm \mathrm{SE}$ ).

Estimates of the grazing rate of Collodictyon triciliatum ranged between 1.1 and 9.9 Microcystis aeruginosa cells flagellate $\mathrm{e}^{-1} \mathrm{~h}^{-1}$ and those of clearance rates between 0.69 and $4.1 \mathrm{nl}$ flagellate ${ }^{-1} \mathrm{~h}^{-1}$ (Table 1). Hourly consumption of $C$. triciliatum on the $M$. aeruginosa population was estimated from 0.002 to $0.09 \%$ of the cyanobacterial standing stock.

\section{DISCUSSION}

There is still limited information concerning the digestion of flagellates feeding on cyanobacteria. Dolan \& Šimek (1998) reported that the digestion rate constant of Bodo saltans feeding on Synechococcus at $22^{\circ} \mathrm{C}$ ranged between 0.9 and $1.1 \%$ cell contents $\mathrm{min}^{-1}$. In the present study, the digestion rate constant of Collodictyon triciliatum feeding on Microcystis aeruginosa was $0.74 \pm 0.02 \%$ cell contents $\mathrm{min}^{-1}$, roughly agreeing with that of Dolan \& Šmek (1998). Furthermore, ingested $M$. aeruginosa cells in C. triciliatum did show an exponential decline with time and the pattern is consistent with that of Dolan \& Šimek (1998). Thus, we consider that the digestion rate constant obtained in the present study is plausible, although the prey and grazer organisms are different from those of Dolan \& Šimek (1998). 
We did not examine size-selectivity of Collodictyon triciliatum in the present study, but judging from the vacuole contents, the flagellate grazed not only unicellular Microcystis aeruginosa but also its colonial form that consisted of from 2 to 51 cells. Mischke (1994) and Klaveness (1995) also noted that this flagellate is capable of grazing on various sizes of phytoplankton, and thus, has a wide size range of edible prey.

The only comparative information available on grazing rates of flagellates feeding on Microcystis aeruginosa is from Cole \& Wynne (1974). They reported that the grazing rate on $M$. aeruginosa by the chrysomonad Ochromonas danica in a laboratory system was on average $1.7 \mathrm{M}$. aeruginosa flagellate ${ }^{-1} \mathrm{~h}^{-1}$ at $23^{\circ} \mathrm{C}$. Thus, estimates of grazing rates in the present study (Table 1) were at the same level as that of Cole \& Wynne (1974). However, if we converted the grazing rates into volume-specific clearance rates using the cell volume of $O$. danica in Chrzanowski \& Šimek (1990), the clearance rates of Collodictyon triciliatum and $O$. danica were respectively estimated as $0.5 \times 10^{3}$ and $1.3 \times 10^{4} \mathrm{~h}^{-1}$. Thus, the latter is 26 times higher than the former. These results may be due to the difference in feeding mode of the flagellates: $C$. triciliatum captures its prey using a pseudopodium-like organelle (Mischke 1994), while chrysomonads use their flagella to generate enough water current to transport their prey (Fenchel 1986). C. triciliatum needs 10 to $30 \mathrm{~min}$ for complete uptake of prey due to its feeding mode (Mischke 1994).

To examine the importance of Microcystis aeruginosa as food for Collodictyon triciliatum, we estimated growth rates of the flagellate. We calculated the carbon content of the flagellate using the cell volume of $4557 \mathrm{\mu m}^{3}$ determined from our measurements of 165 flagellate cells and the volume-to-carbon conversion of

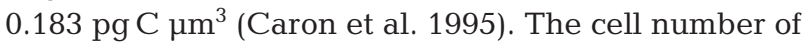
ingested $M$. aeruginosa was converted into carbon amount using a factor of $12.89 \mathrm{pg} \mathrm{C}$ cell $^{-1}$ (Ichise et al. 1995). Thus, it is estimated that consumption of $M$. aeruginosa supplies carbon to the flagellate at a rate of 1.6 to $15.3 \%$ (mean $\pm \mathrm{SD}, 5.5 \pm 3.2$ ) to its cellular carbon content per hour. Assuming that growth of the flagellate is based only on carbon ingested from $M$. aeruginosa, we can calculate a potential growth rate. The growth rates of the flagellate are estimated as 0.0047 to $0.045 \mathrm{~h}^{-1}$ (mean $\pm \mathrm{SD}, 0.016 \pm 0.009$ ), by assuming a gross growth efficiency of 0.42 (Caron et al. 1986), which overlap those in previous laboratory studies where various algal species were used as prey for isolated C. triciliatum (Mischke 1994, Klaveness 1995). Hence, we suggest that consumption of $M$. aeruginosa supports a significant portion in carbon uptake of $C$. triciliatum in this pond.
In Furuike Pond, another important consumer of Microcystis aeruginosa is the rotifer Brachionus calyciflorus, which is usually abundant during summer and early fall. This rotifer has been shown by Jarvis et al. (1987) and Fulton \& Paerl (1987) to effectively graze $M$. aeruginosa so we made a comparison between hourly grazing impact on M. aeruginosa by Collodictyon triciliatum and $B$. calyciflorus. To calculate the hourly grazing impact on $M$. aeruginosa by B. calyciflorus, we used the following information: the individual density of B. calyciflorus during August to October 1998 (35 to 382 ind. $\mathrm{l}^{-1}$, Nishibe et al. unpubl. data), the cell densities of $M$. aeruginosa during the same period ( 0.48 to $18.9 \times 10^{6}$ cells ml $^{-1}$, Manage et al. 2001), and the clearance rate on $M$. aeruginosa by $B$. calyciflorus (5 $\mathrm{\mu l}$ ind. $\mathrm{h}^{-1}$, Starkweather \& Gilbert 1977). This information provided a grazing impact of 0.02 to $0.2 \% \mathrm{~h}^{-1}$ (mean $\pm \mathrm{SD}, 0.09 \pm 0.05$ ), which was similar to that of $C$. triciliatum (Table 1). Thus, we can suggest that the grazing pressure on $M$. aeruginosa by the 2 grazers $C$. triciliatum and $B$. calyciflorus is of minor importance in Furuike Pond, though we do not have a simultaneous determination of grazing impact by the rotifer in the present study. Small ciliates, such as Cyclidium glaucoma and Halteria grandinella, are frequently abundant in the pond (Nakano et al 1998, 2001b), and are known to be efficient filter feeders of picoplankton (Šimek et al. 1996). Hence, one may think that these ciliates are potential grazers of $M$. aeruginosa in the pond. In the preliminary study where we examined which protists grazed M. aeruginosa, however, no cells of the cyanobacterium were found in food vacuoles of these ciliates and, thus, we think that grazing on the cyanobacterium by these ciliates is negligible in this pond. Manage et al. $(1999,2001)$ have suggested that cyanophages and algicidal bacteria cause the sudden collapse of $M$. aeruginosa blooms in Furuike Pond. Thus, not only grazing but also viral and bacterial attack should be examined to elucidate loss processes of $M$. aeruginosa populations.

We could not explain the changes in abundance of Collodictyon triciliatum in relation to water temperature, chl a concentration or abundance of Microcystis aeruginosa. The concentration of chl a was high, ranging between 213.2 and $581.2 \mathrm{\mu g} \mathrm{l}^{-1}$ in the present study, and is sufficient for food requirement of $C$. triciliatum (Mischke 1994). Hence, bottom up control may be of minor importance for changes in abundance of $C$. triciliatum, and we should also examine top down control. In this context it is appropriate that we examine predation on ciliates by metazooplankton since the size of this flagellate is similar in size to the small ciliates which are numerically dominant in the pond (Nakano et al. 1998). In Furuike Pond, predation by metazooplankton is, seasonally, one of the significant 
loss processes of ciliates (Nakano et al. 2001b). Hence, the predation by metazooplankton may be responsible for control of $C$. triciliatum abundance.

We have demonstrated a tight food linkage between Collodictyon triciliatum and Microcystis aeruginosa in Furuike Pond, though the grazing impact of the flagellate may be of minor importance to the decline of the cyanobacterium abundance. It is also suggested that the cyanobacterium is one of the important food sources for the flagellate. Further quantitative studies are required to clarify the trophic interactions between M. aeruginosa and protists in natural environments.

Acknowledgements. We are grateful to the National Institute for Environmental Studies in Japan for kindly supplying us with the algal strain. We thank M. M. Pathmalal, M. Hirose, M. Ueki, M. Miyagaki, M. Yokosawa and other members of the Division of Aquatic Biology \& Ecology, Center for Marine Environmental Studies, Ehime University, Japan, for their advice and support in the field sampling. Thanks are also due to Dr. Mary Morris for her correction of English. The Laboratory of Marine Biodiversity, Graduate School of Fisheries Sciences, Hokkaido University, also provided logistical and financial support of the data analysis and manuscript preparation, for which Y.N. is grateful.

\section{LITERATURE CITED}

Caron DA, Goldman JC, Dennett MR (1986) Effect of temperature on growth, respiration, and nutrient regeneration by an omnivorous microflagellate. Appl Environ Microbiol 52:1340-1347

Caron DA, Dam HG, Kremer P, Lessard EJ and 6 others (1995) The contribution of microorganisms to particulate carbon and nitrogen in surface waters of the Sargasso Sea near Bermuda. Deep-Sea Res I 42:943-972

Chrzanowski TH, Šimek K (1990) Prey-size selection by freshwater flagellated protozoa. Limnol Oceanogr 35: 1429-1436

Cole GT, Wynne MJ (1974) Endocytosis of Microcystis aeruginosa by Ochromonas danica. J Phycol 10:397-410

Dolan JR, Šimek K (1997) Processing of ingested matter in Strombidium sulcatum, a marine ciliate (Oligotrichida). Limnol Oceanogr 42:393-397

Dolan JR, Šimek K (1998) Ingestion and digestion of an autotrophic picoplankter, Synechococcus, by a heterotrophic nanoflagellate, Bodo saltans. Limnol Oceanogr 43: 1740-1746

Dolan JR, Šimek K (1999) Diel periodicity in Synechococcus populations and grazing by heterotrophic nanoflagellates: analysis of food vacuole contents. Limnol Oceanogr 44: 1565-1570

Dryden RC, Wright SJL (1987) Predation of cyanobacteria by protozoa. Can J Microbiol 33:471-482

Fenchel T (1975) The quantitative importance of the benthic microfauna of an arctic tundra pond. Hydrobiologia 46: 445-464

Fenchel T (1986) The ecology of heterotrophic microflagellates. Adv Microb Ecol 9:57-97

Fulton RS III, Paerl HW (1987) Toxic and inhibitory effects of the blue-green alga Microcystis aeruginosa on herbivorous zooplankton. J Plankton Res 9:837-855
Gonzalez JM, Sherr EB, Sherr BF (1990) Size-selective grazing on bacteria by natural assemblages of estuarine flagellates and ciliates. Appl Environ Microbiol 56:583-589

Ichise S, Wakabayashi T, Matsuoka Y, Yamanaka S, Fujiwara N, Tanaka K (1995) A simple method for the estimation of phytoplankton biomass based on cell morphology in Lake Biwa. Rep Shiga Pref Inst Pub Health Environ Sci 30: 27-35 (in Japanese)

Jarvis AC, Hart RC, Combrink S (1987) Zooplankton feeding on size fractionated Microcystis colonies and Chlorella in a hypertrophic lake (Hartbeespoort Dam, South Africa): implications to resource utilization and zooplankton succession. J Plankton Res 9:1231-1249

Kamiyama T, Takayama H, Nishii Y, Uchida T (2001) Grazing impact of the field ciliate assemblage on a bloom of the toxic dinoflagellate Heterocapsa circularisquama. Plankton Biol Ecol 48:10-18

Klaveness D (1995) Collodictyon triciliatum H. J. Carter (1865) - a common but fixation-sensitive algivorous flagellate from the limnopelagial. Nordic J Freshw Res 70: $3-11$

Kopylov AI, Tumantseva NI (1987) Analysis of the contents of tintinnid food vacuoles and evaluation of their contribution to the consumption of phytoplankton production off the Peru coast. Oceanology 27:343-347

Li A, Stoecker DK, Coats DW (2001) Use of the 'food vacuole content' method to estimate grazing by the mixotrophic dinoflagellate Gyrodinium galatheanum on cryptophytes. J Plankton Res 23:303-318

Manage PM, Kawabata Z, Nakano S (1999) Seasonal changes in densities of cyanophage infectious to Microcystis aeruginosa in a hypereutrophic pond. Hydrobiologia 411:211-216

Manage PM, Kawabata Z, Nakano S (2001) Dynamics of cyanophage-like particles and algicidal bacteria causing Microcystis aeruginosa mortality. Limnology 2:73-78

Mischke U (1994) Influence of food quality and quantity on ingestion and growth rates of three omnivorous heterotrophic flagellates. Mar Microb Food Webs 8:125-143

Moran R, Porath D (1980) Chlorophyll determination in intact tissues using N, N-dimethylformamide. Plant Physiol 65: $478-479$

Nakano S, Ishii N, Manage PM, Kawabata Z (1998) Trophic roles of heterotrophic nanoflagellates and ciliates among planktonic organisms in a hypereutrophic pond. Aquat Microb Ecol 16:153-161

Nakano S, Hayakawa K, Frenette JJ, Nakajima T, Jiao C, Tsujimura S, Kumagai M (2001a) Cyanobacterial blooms in a shallow lake: a large-scale enclosure assay of the importance of diurnal stratification. Arch Hydrobiol 150: 491-509

Nakano S, Manage PM, Nishibe Y, Kawabata Z (2001b) Trophic linkage among heterotrophic nanoflagellates, ciliates and metazoan zooplankton in a hypereutrophic pond. Aquat Microb Ecol 25:259-270

Paerl HW, Tucker J, Bland PT (1983) Carotenoid enhancement and its role in maintaining blue-green algal (Microcystis aeruginosa) surface blooms. Limnol Oceanogr 28: $847-857$

Reynolds CS, Jaworski GHM, Cmiech HA, Leedale GF (1981) On the annual cycle of the blue-green alga Microcystis aeruginosa Kütz. emend. Elenkin. Phil Trans R Soc Lond Ser B 293:419-477

Rublee PA, Gallegos CL (1989) Use of fluorescently labelled algae (FLA) to estimate microzooplankton grazing. Mar Ecol Prog Ser 51:221-227

Sanders RW, Porter KG, Bennett SJ, DeBiase AE (1989) Seasonal patterns of bacterivory by flagellates, ciliates, 
rotifers and cladocerans in a freshwater planktonic community. Limnol Oceanogr 34:673-687

Sherr EB, Sherr BF, McDaniel J (1991) Clearance rates of $<6 \mu \mathrm{m}$ fluorescently labeled algae (FLA) by estuarine protozoa: potential grazing impact of flagellates and ciliates. Mar Ecol Prog Ser 69:81-92

Šimek K, Chrzanowski TH (1992) Direct and indirect evidence of size-selective grazing on pelagic bacteria by freshwater nanoflagellates. Appl Environ Microbiol 58: $3715-3720$

Šimek K, Macek M, Pernthaler J, Straškrabová V, Psenner R (1996) Can freshwater planktonic ciliates survive on a diet of picoplankton? J Plankton Res 18:597-613

Starkweather PL, Gilbert JJ (1977) Radiotracer determination of feeding in Brachionus calyciflorus: the importance of

Editorial responsibility: Karel Šimek,

České Budějovice, Czech Republic gut passage times. Arch Hydrobiol Beih Ergebn Limnol 8: 261-263

Sugiura N, Inamori Y, Ouchiyama T, Sudo R (1992) Degradation of cyanobacteria, Microcystis by microflagellate, Monas guttula. Water Sci Technol 26:2173-2176

Takamura N, Iwakuma T, Yasuno M (1985) Photosynthesis and primary production of Microcystis aeruginosa Kütz. in Lake Kasumigaura. J Plankton Res 7:303-312

Zhang X, Watanabe MM, Inouye I (1996) Light and electron microscopy of grazing by Poterioochromonas malhamensis (Chrysophyceae) on a range of phytoplankton taxa. J Phycol 32:37-46

Zohary T, Robarts RD (1989) Diurnal mixed layers and the long-term dominance of Microcystis aeruginosa. J Plankton Res 11:25-48

Submitted: November 17, 2001; Accepted: July 8, 2002 Proofs received from author(s): August 27, 2002 